\title{
Intensification the Role of Parent for Learning Assistance Model at Home in The New Normal Era
}

\author{
Sujarwo ${ }^{1}$ Erma Kusumawardani ${ }^{2 凶}$, Iis Prasetyo ${ }^{3}$, Adin Ariyanti Dewi ${ }^{4}$ \\ Pendidikan Luar Sekolah, Universitas Negeri Yogyakarta(1,2,3,4) \\ DOI: $\underline{10.31004 / \text { obsesi.v6i1.1213 }}$
}

\begin{abstract}
This activity aims to carry out a model of children's learning assistance through optimizing the role of parents to be more enthusiastic in facing this new normal era. Not a few parent feel confused and difficult in assisting their children in learning. This research used participatory action research method. The program target of this activity is 30 parent and 15 facilitator from 'keluarga harapan' program. It can be seen that the activities carried out have optimized various parties and can achieve the expected output. Based on the activity, beneficiary families are motivated and have high enthusiasm in spreading the knowledge and skills they have acquired to other families. So, from this activity the community service team highlighted several important things that have been done starting from paying attention to the concept of adult learning, strengthening the focus on social capital and also introducing the importance of peer teaching.
\end{abstract}

Keywords: assistance; learning at home; parent; covid-19 pandemic

\begin{abstract}
Abstrak
Kegiatan ini bertujuan untuk melaksanakan model pendampingan belajar anak melalui optimalisasi peran orang tua agar lebih semangat dalam menghadapi era normal baru ini. Tidak sedikit orang tua yang merasa bingung dan kesulitan dalam mendampingi anaknya dalam belajar. Penelitian ini menggunakan metode penelitian tindakan partisipatif. Sasaran program dari kegiatan ini adalah 30 orang tua dan 15 fasilitator dari program 'keluarga harapan'. Terlihat bahwa kegiatan yang dilakukan telah mengoptimalkan berbagai pihak dan dapat mencapai output yang diharapkan. Berdasarkan kegiatan tersebut, keluarga penerima manfaat termotivasi dan memiliki semangat yang tinggi dalam menyebarkan ilmu dan keterampilan yang mereka peroleh kepada keluarga lain. Maka dari kegiatan ini tim pengabdian masyarakat menyoroti beberapa hal penting yang telah dilakukan mulai dari memperhatikan konsep pembelajaran orang dewasa, memperkuat fokus pada modal sosial dan juga mengenalkan pentingnya peer teaching.
\end{abstract}

Kata Kunci: pendampingan; belajar di rumah, orangtua, pandemic covid-19

Copyright (c) 2021 Sujarwo, Erma Kusumawardani, Iis Prasetyo, Adin Ariyanti Dewi

$\triangle$ Corresponding author:

Email Address : ermakusumawardani@uny.ac.id (Yogyakarta, Indonesia)

Received 22 March 2021, Accepted 4 April 2021, Published 8 March 2021 


\section{INTRODUCTION}

The corona virus pandemic (covid-19) has resulted in sudden changes in the daily lives of individuals and community activities, bringing about tremendous change impacts for all fields. One of them is in the field of education, so learning from home is a necessity. Almost all countries then implemented a learning from home system. The issuance of circular number 4 of 2020 concerning the implementation of education in the Covid-19 emergency period that the application of learning from home does not mean that educators only give assignments to students, but also communicate with parents (Trisnawati \& Sugito, 2020). Learning activities at home show that technology disruption occurs in the world of education, face-to-face learning which is implemented 100 percent in schools, suddenly undergoes very drastic changes. Learning from home is still felt by some educators, students, and even parents. Thus, all lines of society are forced to transform and adapt to this pandemic. This condition provides an understanding that technology is a solution in overcoming the impact in the field of education, namely through distance learning strategies. However, this strategy is still difficult for all levels of society to accept. The lack of uniformity in the learning process, both related to the standards and quality of the desired learning outcomes, is still a big problem in the world of education. A sudden change in the learning system that has turned online. In addition to creating physical and mental pressure on students, teachers and even parents, it also makes it difficult for schools to make benchmarks for the same learning outcomes. Even the gap occurs due to the inequality of learning facilities which include internet connectivity and communication equipment such as laptops or smartphones.

From data on preliminary study it can be seen clearly in the community during the Covid 19 pandemic, such as the middle and lower class groups. Some still have difficulty operating and accessing the internet. This then becomes the basis for a situation analysis on the conditions of the parents of the beneficiary families from the "Keluarga Harapan" Program $(\mathrm{PKH})$. Even though the amount of aid given is increasing and decreasing every month, it turns out that there are still some very striking obstacles. That is inseparable from the goals of the "Keluarga Harapan" Program (PKH) itself in the education sector. PKH program assistants who have the task and role in increasing parental awareness in children's education, are currently experiencing changes in their efforts to continue to motivate parents in assisting children's learning in particular. Because this is a challenge for parents, based on the results of interviews so far parents have fully entrusted education in educational institutions for their children to go to school. Then later in this pandemic, parents experienced culture shock because they had to be faithful to accompany their children to study even outside of school hours. This is due to the condition of parents who also have to play around with their minds to meet their daily needs because the income from daily work has decreased, as well as some parents who have been affected by the breakdown of work relations.

Transformation and adaptation make the role of parents the key to success in dealing with this situation. Parents as the first door to this change. Parents must be able to transform and adapt first, so that parents can become companions or mentors of change for their children at home. It can be known together that all parents hope their children become well educated or educated people. The problems that will arise in the future will certainly be more complex and complicated. An educated person, characterized by a complete perspective, and good behavior in dealing with various problems. This pandemic period is an opportunity to make every parent aware that the burden of children's education cannot just be left to educators alone.

Parents who become mentors and mentors at home are role models for changing attitudes for students in their behavior and facing current problems. Optimal parental assistance in online learning mechanisms is needed. The effectiveness of communication between parents and children is needed (Batoebara \& Hasugian, 2021). Parents must be able to study again with their children at home. At the same time, instilling a positive mindset so that facing this pandemic is a new lifestyle that must be accustomed to living. Then remind 
again that learning does not only focus on the object being studied, but every educator and learner also focuses on how to think and behave towards what they learn. This means that the realm of learning does not only include expertise, not only knowledge, but also includes a mindset in dealing with a problem.

With the formation of a mindset that is ready to excel in facing the complexities and complexities that will arise in the future, it becomes an important provision for every individual. In addition, he continued, a positive mindset is a sufficient condition so that someone has good communication skills and also behaves well. A positive mindset will facilitate the implementation of any learning material needed by learners. This is where the role of the parents as mentor and also the real role models. Nelson Mandela quotes that education is the most powerful weapon that can be used to change the world. Malcolm X also believes that education is a passport for the future, therefore tomorrow belongs to those who prepare themselves for today. Nature education, which is also inseparable from Ali Bin Abi Talib's quote, also reminded him to educate children according to their times, because they lived not in yours.

"Keluarga Harapan" Program (PKH) is a program for providing conditional social assistance to Poor Families who are designated as PKH beneficiary families. Through this program, program recipients are encouraged to take advantage of basic services such as education and health. With the Covid-19 pandemic, beneficiary families received a tremendous impact. Based on interviews conducted with PKH program recipients in Pandak District, PKH beneficiary families felt that their husbands received a reduction in their income. There is also her husband who was laid off (termination of employment) due to the covid-19 virus. In addition, families who usually make snacks have to reduce production due to the decline in buyers. The research result from (Uzun et al., 2021) shows that spouse support within the family positively effects the relations of mothers with their children during the quarantine process, in which the rates of families receiving financial and moral support from outside have decreased. On the other hand, the research results revealed that low-income and lower-middle class parents, as well as parents of color, experienced more instrumental and financial hardships due to the pandemic, when compared to their higher income, White counterparts. In contrast, parents with higher income and White parents were more likely to feel stressed over structuring home learning environments and planning educational and physical activities at home for their children. The overall findings suggest that family income level and race / ethnicity play a significant role in the lives of families coping with a variety of challenges due to the pandemic (Chen et al., 2021). Family emotional reactions (positive and negative) that emerged related to family resilience during Covid 19 from differences in family types, family socioeconomic levels (parent work) and types of family residential areas showed significant differences in family resilience during the Covid 19 isolation period (Ramadhana, 2020).

Most of the beneficiary families in the Covid-19 pandemic situation are spent at home. This is due to several government policies such as social distancing, psychological distancing, work from home, and study from home for school-age children. The government policy for students to study at home requires parents to pay attention to children's learning activities at home. Not a few beneficiary families experience confusion and difficulty in assisting their children in learning. There are difficulties that parents feel in the PJJ program, namely; signals, work, time to accompany children to study, learning methods, children's focus on learning, materials that are difficult to find, collection of assignments in the form of videos, parents do not understand IT, regulate children's emotions when learning, finances, children only obey the teacher (Wijayanti \& Fauziah, 2020). The new coronavirus (COVID-19) pandemic caused the daily life changes, the in a situation that is largely authentic for millions of families worldwide. Families are under a significant stress, and parents may experience greater psychological distress and disruptions in the parent - child relationship (Riegler et al., 2020). There was a significant increase in parenting stress in the pandemic era (Hiraoka \& Tomoda, 
2020). Parents find it difficult to deal with children's behavior during the Covid-19 pandemic. Children have difficulty in learning because most teachers give assignments to students without giving explanation. Children tend to find it difficult to do learning at home and parents find it difficult in providing assistance to their children. So, based on this situation analysis, the basis for service activities that will be analysis the obstacle from parent when assistance their children. However, it can be see the best model for child learning assistance model activities through optimizing the role of parents to be more enthusiastic in facing this new normal era. Because of this new normal era, there will certainly be more changes in society.

\section{METHOD}

This research is focused on problem solving efforts in one particular group. so this research uses a participatory action research. The program target of this activity is beneficiary families totaling 30 parent and 15 facilitator from 'keluarga harapan' program. The characteristics of the target group in this study are parents who have school-age children from elementary to high school levels. Selection of subjects using purposive sampling technique. Activities have been carried out according to plans and objectives in accordance with the issues raised. It can be seen that the activities carried out have optimized various parties and can achieve the expected output. Data collection using open question questionnaire, observation, interview and documentation techniques. The questionnaire was developed based on a grid of instruments arranged according to the aspects raised. Questionnaire as a technique used in the preliminary study which has been validated by experts. Interviews were conducted when researchers conducted a focus group discussion. Observations are carried out from the preliminary study to the end of the study. Documentation study as secondary data. So that the validity of the data from this study used triangulation of techniques, sources and time. Qualitative data analysis is used to process all the information obtained. Data analysis activities carried out from the reduction stage, data presentation to drawing conclusions. The implementation of this activity has been carried out in several stages according to the target group who are adults. Then the implications regarding adult education starting from planning, implementation, evaluation, and follow-up as.

\section{RESULT AND DISCUSSION}

The Covid 19 pandemic has become one of the most extraordinary events that have occurred throughout the world. Many Indonesian people in particular have been affected because of the effects of this Covid pandemic. Indonesia has experienced a condition where the public's concern about Covid-19 is quite large, so a government policy is needed to carry out a lockdown, as an effort to break the chain of spreading the Covid-19 corona virus (Nur Rohim Yunus, 2020). Changes in society due to efforts to adapt are observed from life patterns and changes in behavior. The specific impacts on the beneficiary families of the family hope program are on economic instability. Some beneficiary families experienced job changes, decreased income and even lost their jobs. This condition then affected the condition of some parents which was added to the concept of studying at home which made some parents object and become a burden. Yet if you recall the concept of fitrah education that parents are the primary and first educators. Parents who like it or not in a situation like this must accompany their children to study every day, of course it cannot be separated from several obstacles. Among them, parents have difficulty understanding the current curriculum learning, the sharing of time with work that is also required more because of decreased family income, emotional conditions that are often provoked by being left with children, to learning that is required to be completely online and digital, of course some difficulties in errors and the availability of internet networks. to access learning. Some of these conditions then become an attraction for non-formal education practitioners to carry out activities in the child learning assistance model, which is inseparable from the role of parents in facing this new normal era. 
Because some schools in the green zone will start face-to-face at the end of the year for children who are at the elementary and old school levels. However, until now, in particular the Special Region of Yogyakarta is still in the orange zone, which indicates that children are still being asked to learn from home.

The impact that was felt from the Covid 19 pandemic was felt more by the middle to lower class groups. Where the majority of community jobs are in the informal sector. The decrease in income to the loss of work has been felt by some of the people who are in the informal sector since the imposition of large-scale social restrictions. People who are asked to prioritize health and safety, of course also think harder in fulfilling their daily needs. Besides that, parents are also asked to always accompany their children to study since learning at home is implemented by each educational institution, both public and private. Conditions in the beneficiary families of the Harapan Family program that experience obstacles in accompanying children's learning. Both from the provision of time, the ability to accompany to regulate emotions when learning children and facilities that can support children's learning. This is a fundamental problem in the service activities that will be carried out. Then based on these conditions, then innovations to carry out child learning assistance model activities through optimizing the role of parents will be endeavored to face the new normal era in this pandemic. Because indirectly the new normal era, people will be required to adapt again. Some educational institutions will also be started face-to-face in the green zone, of course this will create more gaps for parents. Because there are many parents who perceive this as a burden and are not the responsibility of the parents. Yet if you look at the concept of 'fitrah' education, parents are the primary and first educators for children.

Based on the results of distributing questionnaires to find out the problems faced by parents while accompanying children to study at home. The results of the data obtained, obtained some information that the majority of learning assistance activities are still carried out by mothers. On the other hand, the majority of mothers who were research subjects also had full-time jobs in the private sector. Of course, this cannot be separated from the fulfillment of daily needs. Thus it can be concluded that the mother is then reminded of her role as the primary and first educator. The phenomenon of studying at home is then completely accompanied by parents. Mentoring efforts are carried out by parents in various ways, such as helping children when they feel difficulties, conducting teaching, or doing online learning (Kurniati et al., 2020). However, based on the initial survey there are still some obstacles faced by parents in accompanying children to learn, including none other than the understanding of parents in maximizing the learning platform and understanding of the substance of learning material which is considered increasingly difficult. On the other hand, many parents still complain about their limited time in accompanying their children. This is related to the time management of parents who still feel difficult.

Problems that were carried out during the preliminary study which later became the basis for the implementation of giving activities as a form of action to help solve problems. The form of activity is in the form of education and training activities. The implementation of socialization by providing the most important materials with learning assistance is one of the efforts that can be made to increase understanding for parents in accompanying children to learn (Nurpratiwiningsih et al., 2021). The implementation of activities is carried out in the Pandak sub-district offline by paying attention to health protocols. This activity was attended by 30 beneficiary families, which was taken by one representative from each hamlet. In addition, this activity is also accompanied by PKH Facilitators as a figure directly related to KPM. The activities carried out have provided benefits to the target group which includes knowledge and skills. This activity is carried out through various stages from preparation to evaluation. This activity begins with coordinating with related parties to determine the time and prepare the equipment and materials needed. Apart from technical needs, an initial survey was also carried out, assisted by field assistants to determine the condition of the target groups. The survey was conducted after distributing questionnaires online to see the initial 
understanding of beneficiary families. The activity is carried out in Pandak District while still paying attention to the protocol from the Ministry of Health. Understanding the material from the resource persons that currently parents as the Main Madrasah must be able to provide assistance in the form of mastery of technology and learning assistance. If not able, must seek help from others so that the child learns smoothly. No less important is providing supporting facilities, namely internet quota, gadgets and books. There are many cases in society that occur that technological sophistication causes children to be technology dependent, believe in technology without filters, and give less importance to knowledge from parents. Furthermore, the material description also provides technical details on how educators work in the pandemic era. The explanation from the speaker was able to convince the participants that the teacher was also not just silent, but actively learning how, not face to face, the interaction between teacher and students remains smooth. The essence of learning assistance in this new normal era is the importance of collaboration between the three education centers in order to create meaningful learning. Then the next event is to strengthen the target group through informal Focus Group Discussion (FGD) activities. From the activities carried out which then adds to the understanding again of the importance of mentoring children which is more focused on a psychological point of view.

Based on the activities carried out, this provides knowledge and skills in accompanying children to study at home in the new normal era. The participants / target groups were very enthusiastic about participating in a series of activities carried out. In general, this activity was successfully carried out, the participants gained knowledge and skills, previously they did not know the tips for assisting children to study at home during this pandemic, now they are more able to understand children while learning. As stated by (Iverson, 2001), skills require training and basic abilities that everyone has in order to help produce something more valuable more quickly. The first mentoring material raised was related to "Meaningful Learning in the New Normal Era". That in education, parents must look at their children when studying at home. When a pandemic occurs, around the end of 2019 there must be new adaptations when studying at home, working at home, and worshiping at home. The first two weeks of Lock Down and feeling lonely, work did not go well. So that many parents or students experience changes in learning activities. The positive thing is that parents appreciate the teaching profession. The learning flow at home is carried out in several stages, namely 1) The teacher provides learning materials, 2) Learning is carried out online, 3) Students learn and do assignments, 4) The teacher monitors, 5) The teacher provides an explanation. The concept of a new learning flow naturally adapts to new conditions currently that must be side by side with the corona virus so that learning is more focused on online / virtual learning. So that assistance becomes important, so that children do not just memorize and understand all the material on the internet. Because it will be easy to provoke.

This meaningful learning is also intended for children under five. How to assist toddlers in learning. What needs to be understood is that toddlers have a high interest in parental activities, therefore they must be accustomed to being involved in parental activities even if only a little. Children, when helping and never getting angry with, will make them more confident. Training children cannot be forced, but made interesting. For example, when children are curious about something, they are asked to learn to read. What often happens is that parents always force their children, making them stressful. The development of the child will be better if it is natural. Teaching the child is like writing on a rock. Difficult but lasting. Sometimes it takes a long time, but you have to be patient. So far, the classical method still remains, but has used a new method. Parents' job is to assist optimally. Parents must also learn to improve their abilities, as well as those around them, to support their children. So what is needed is to find solutions and enthusiasm for learning in various limitations, including following online learning. As well as the optimization of the three education centers. Accompanying children must start from daily activities. Because the roles of mothers and fathers in society are examples of children. If there is a download task, install it on a cellphone 
and others, including the duties of parents when learning online. If you are already in junior high school, it is enough to accompany the learning process. Study results suggested that parents' mental health may be an important factor linked to at-home education and child wellbeing during the pandemic (Lee, S. J., Ward, K. P., Chang, O. D., \& Downing, 2020). Dealing with the lockdown is a stressful experience for parents who have to balance personal life, work, and children upbringing, without other help. This situation potentially impairs their ability to be supportive caregivers and is consequently detrimental for children well-being. Policies should take into consideration the implications of the lockdown for families' mental health and tailor supportive interventions according to family's risk factors (Spinelli et al., 2020).

Learning with this online system has positive and negative impacts for students and parents. One of the negative impacts is the unpreparedness of parents in child learning assistance (Suprihatin et al., 2020). The pattern of learning assistance carried out by parents to children during this pandemic experienced a difference when compared to the period before the Covid-19 pandemic. These differences can be seen in terms of the method or form of learning assistance, intensity, learning time and even the attitudes applied by parents to their children while studying from home (Nia Unfa, 2020). The concept of learning means changing from habitual learning to learning that seeks to create. Or behavioristic to constructivist so that it is more on forming a new science. Often children's knowledge matches the knowledge of their educators. Tasting bitter coffee rather than being told bitter coffee. Often the expectations of children with parental circumstances are different. When a child meets a parent, the child wants to meet optimally, but the parents are tired. Therefore it is given understanding. Then, there is a sense of pride when parents are involved in children's activities. Recreation can be done at home, for example playing kites, etc. which involve the activities of children and parents. Parents are examples of children. So that children always imitate their parents. Considering the importance of the three education centers, the assistance materials were also brought in from formal school practitioners. Where participants know how efforts to achieve children's competence are always pursued with various activities. Starting from optimizing online learning to home visit activities conducted by teachers. Which is the plan in September the school has conducted face-to-face health protocols. You are not allowed to open a school if you are not able to comply with health protocols. It should be noted that in accompanying children to learn, it must be done with patience and compassion. Over time, children do not need to be accompanied to learn independently. Based on the discussion of questions and answers, for children who are already in junior high school, when learning online, the knowledge between children and parents is different. The result from Learning assistance for children can be seen from the way parents help children's task difficulties, explain material that is not understood children, and responds well to all online learning from the school (Yulianingsih et al., 2020).

Learning at home increases the stressor and responsibility burden of a mother who is considered the most responsible for childcare (Citra \& Arthani, 2020). In order for good relations with children, then the last strengthening activity carried out was by providing motivation to the target group. As for efforts to overcome parental assistance, namely communication between parents and teachers, providing opportunities or trust, and providing motivation (Rahmania et al., 2021). Providing motivation, of course, begins with raising awareness of the conditions of each in the family. After that, understand the problems that often occur in families that often affect children. So that by doing so, participants are able to draw conclusions on what actions are appropriate and appropriate to be implemented in their respective families based on several forms of reinforcement conveyed through discussions. But on the other hand, teachers also need to learn more through effective, efficient and fun teaching training through electronics such as webinars that are widely provided by the 
government and other private educational institutions (Widiastuti et al., 2020). The application of good parenting can be realized through treatment, attention, fulfillment of needs, and the attitudes of parents in daily life which can affect children's learning motivation. Parenting patterns that are applied to the characteristics of children include 1) religious, 2) discipline, 3) independent, 4) communicative, 5) tolerance, 6) respect for achievement. Children not only get maximum learning motivation but have good character education in an effort to prepare future generations to give a positive attitude, appropriate treatment from parents in educating children, it will be easier to increase children's motivation in learning (Fatmawati et al., 2021).

From the strengthening activities which later also gave rise to the social capital of the beneficiary families who participated in the activities. Given that the activities carried out from beginning to end are representatives of each hamlet, so that participants can exchange knowledge. Furthermore, the group then forms a new learning community which aims to share information and share with other beneficiary families. The activities carried out are of course using the adult learning method by remembering that adults have experience. So that in delivering the material, the presenters have departed from the experiences of the participants and also provided tips that can be applied directly by the participants through learning by doing. Adult learning is a process that fosters the desire to ask questions and learn continuously throughout life. For adults, learning is related to how to direct yourself to ask questions and find answers (Novita, 2019). In other words, andragogy is anything that has to do with adult learning and adult education. Adults as learners are very unique and different from early childhood and adolescents. The adult learning process will take place if he is directly involved, his ideas are appreciated and the teaching material is needed or related to his profession as well as something new for him. The principles of adult learning, namely: 1) Adults need to be involved in designing and making learning goals. They must understand the extent to which the results are achieved, 2) Experience is the principle of learning activities. It is the responsibility of students to accept experience as meaningful, 3) Adults are more interested in learning matters directly related to their work and life, 4) Learning is more problem-centered and requires encouragement and motivation (Knowles, 1980). The learning process for adults requires the presence of other people who are able to act as learning guides and do not tend to be patronized, adults tend to want to learn instead of studying. Adults grow as individuals and have a mature self-concept, experience psychological changes and dependence that occurs in childhood to become independent to direct themselves, so that the adult learning process must pay attention to the characteristics of adults.

\section{CONSCLUSION}

Parent are better able to assist children to study at home by understanding their children's learning characteristics. They are motivated in spreading the knowledge and skills they get. Beside that, from paying attention to the concept of adult learning, strengthening the focus on social capital and also introducing the importance of peer teaching. Some suggestions are the need to provide intensive assistance through other activities to monitor the progress and improve the necessary skills. Innovations for other supporting activities also need to be carried out so that the target group is always motivated to gain additional knowledge and new insights.

\section{ACKNOWLEDGMENT}

We would like to thank the members of the research team in the scope of competency and literacy development in the PLS FIP UNY department for their extraordinary collaboration. We don't forget to thank the editors and reviewers who gave us lots of positive feedback as our introspective in preparing this article to make it more readable. 
Intensification the Role of Parent for Learning Assistance Model at Home in The New Normal Era DOI: $10.31004 /$ obsesi.v6i1.1213

\section{REFERENCES}

Batoebara, M. U., \& Hasugian, B. S. (2021). Peran Orang Tua dalam Komunikasi Pembelajaran Daring. Warta Dharmawangsa, 166-176. https://doi.org/10.46576/wdw.v15i1.1058

Chen, C. Y. C., Byrne, E., \& Vélez, T. (2021). Impact of the 2020 pandemic of COVID-19 on Families with School-aged Children in the United States: Roles of Income Level and Race. Journal of Family Issues, 1-22. https:/ / doi.org/10.1177/0192513X21994153

Citra, M. E. ., \& Arthani, N. (2020). Peranan ibu sebagai pendamping belajar via daring bagi anak ada masa pandemi COVID-19. Prosiding Webinar Nasional ..., 71-79. http:/ /ejournal.unmas.ac.id/index.php/prosidingwebinarwanita/article/view/1243

Fatmawati, E., Ismaya, E. A., \& Setiawan, D. (2021). Pola Asuh Orang Tua Dalam Memotivasi Belajar Anak Pada Pembelajaran Daring. Jurnal Educatio FKIP UNMA, 7(1), 104-110. https://doi.org/10.31949/educatio.v7i1.871

Hiraoka, D., \& Tomoda, A. (2020). Relationship between parenting stress and school closures due to the COVID-19 pandemic. In Psychiatry and Clinical Neurosciences (Vol. 74, Issue 9, pp. 497-498). https:// doi.org/10.1111/pcn.13088

Iverson. (2001). Memahami Keterampilan Pribadi. CV. Pustaka.

Knowles, M. S. (1980). The modern practice of adult education, From Pedagogy to Andragogy What Is Andragogy? Business, 400. http://www.amazon.co.uk/dp/0695814729

Kurniati, E., Nur Alfaeni, D. K., \& Andriani, F. (2020). Analisis Peran Orang Tua dalam Mendampingi Anak di Masa Pandemi Covid-19. Jurnal Obsesi : Jurnal Pendidikan Anak Usia Dini, 5(1), 241. https://doi.org/10.31004/obsesi.v5i1.541 https://doi.org/10.31004/obsesi.v5i1.541

Lee, S. J., Ward, K. P., Chang, O. D., \& Downing, K. M. (2020). Parenting Activities and the Transition to Home-based Education During the COVID-19 Pandemic. Children and Youth Services Review, 105585., 8(8), 669. https://doi.org/10.1016/S22138587(20)30235-7

Nia Unfa, A. T. N. (2020). Pola Bimbingan Belajar Orang Tua di Masa Pandemi Covid-19. Academia: Journal of Multidisplinary Studies, 4(December).

Novita, M. W. (2019). Pendidikan Orang Dewasa. https:// doi.org/10.31227/osf.io/b6hsq

Nur Rohim Yunus, A. R. (2020). Kebijakan Pemberlakuan Lockdown Sebagai Antisipasi Penyebaran Corona Virus Covid-19. SALAM: Jurnal Sosial Dan Budaya Syar-I, 7(3). https://doi.org/10.15408/sjsbs.v7i3.15048

Nurpratiwiningsih, L., Yuliyanti, N., \& Kurniawan, P. Y. (2021). Sosialisasi Pendampingan Orang Tua terhadap Proses Belajar Anak selama Masa Pandemi Covid 19. 1(02), 31-36. https:// doi.org/10.22515/literasi.v1i1.3259

Rahmania, S., Wijayanti, R., \& Hakim, S. L. (2021). Strategi Orang Tua Dalam Pendampingan Belajar Anak Selama Pandemi Covid-19. Literasi: Jurnal Kajian Keislaman MultiPerspektif, 1(1), 99-110. https:/ / doi.org/10.22515/literasi.v1i1.3259

Ramadhana, M. R. (2020). Mempersiapkan Ketahanan Keluarga Selama Adaptasi Kebiasaan Baru Di Masa Pandemi Covid-19. Jurnal Kependudukan Indonesia, 2902, 61. https://doi.org/10.14203/jki.v0i0.572

Riegler, L. J., Raj, S. P., Moscato, E. L., Narad, M. E., Kincaid, A., \& Wade, S. L. (2020). Pilot trial of a telepsychotherapy parenting skills intervention for veteran families: Implications for managing parenting stress during COVID-19. Journal of Psychotherapy Integration, 30(2), 290-303. https:// doi.org/10.1037/int0000220

Spinelli, M., Lionetti, F., Setti, A., \& Fasolo, M. (2020). Parenting Stress During the COVID-19 Outbreak: Socioeconomic and Environmental Risk Factors and Implications for Children Emotion Regulation. Family Process, x(x), 1-15. https://doi.org/10.1111/famp.12601

Suprihatin, A., Ananda, T. A., Mahsa, N., Damayanti, W., Alfiyah, G., Nurulita, M. F., \& Arifin, R. (2020). Efektivitas pendampingan belajar anak dalam mengatasi kesulitan orang tua 
saat pembelajaran daring di masa pandemi di desa kebulusan, kabupaten kebumen. 16.

Trisnawati, W., \& Sugito, S. (2020). Pendidikan Anak dalam Keluarga Era Covid-19. Jurnal Obsesi : Jurnal Pendidikan Anak Usia Dini, 5(1), 823-831. https:// doi.org/10.31004/obsesi.v5i1.710

Uzun, H., Karaca, N. H., \& Metin, Ş. (2021). Assesment of parent-child relationship in Covid19 pandemic. Children and Youth Services Review, 120(September 2020). https:// doi.org/10.1016/i.childyouth.2020.105748

Widiastuti, Y. K. W., Rasmani, U. E. E., \& Wahyuningsih, S. (2020). Mengkaji Penerapan ELearning pada Anak Usia Dini. Jurnal Obsesi : Jurnal Pendidikan Anak Usia Dini, 5(2), 1240-1247. https:// doi.org/10.31004/obsesi.v5i2.752

Wijayanti, R. M., \& Fauziah, P. Y. (2020). Perspektif dan Peran Orangtua dalam Program PJJ Masa Pandemi Covid-19 di PAUD. Jurnal Obsesi : Jurnal Pendidikan Anak Usia Dini, 5(2), 1304-1312. https:// doi.org/10.31004/obsesi.v5i2.768

Yulianingsih, W., Suhanadji, S., Nugroho, R., \& Mustakim, M. (2020). Keterlibatan Orangtua dalam Pendampingan Belajar Anak selama Masa Pandemi Covid-19. Jurnal Obsesi : Jurnal Pendidikan Anak Usia Dini, 5(2), 1138-1150. https://doi.org/10.31004/obsesi.v5i2.740 